\title{
Selecting an appropriate multimedia authoring language
}

\author{
ELLEN F. ROSEN \\ College of William and Mary, Williamsburg, Virginia \\ and \\ LINDA C. PETTY \\ Hampton University, Hampton, Virginia
}

\begin{abstract}
Multimedia is the integration of sound, pictures, videos, and text in such a way that users can navigate, explore, investigate, and create. The essence of multimedia computer-based training (CBT) is the use of conditional branching. Five multimedia authoring programs were compared: Multimedia Toolbook CBT, Director, Authorware Professional, IconAuthor, Action!, Quest, and Supercard. Comparisons include such factors as initial cost, distribution costs, platform, metaphor and logic, strengths, and support. The most critical factors, and their order of importance, in selecting an authoring language are delivery platform, level of interactivity required, need for database connectivity, the kind of support available, and the metaphor. We chose Multimedia Toolbook CBT for our use because of the availability of outside support, low cost, platform, the book metaphor, and similarity to other familiar languages (HyperCard and BASIC).
\end{abstract}

A distinction must be made between multimedia and mixed media. Multimedia is the integration of sound, pictures, videos, and text in such a way that users can move, explore, investigate, and create. It is this control by the users that is the critical basic concept of multimedia. Literally, using a projector to show a video and writing key points on the blackboard is multiple media. Use of multiple media, however, does not imply any interactivity for the user. The path is relatively linear; there is no opportunity for active learning, no room for user exploration. The addition of a computer to the media delivery system is the element that makes interactivity possible and is the exciting and revolutionary aspect of computer-based multimedia education. Peterson and Orde (1995) report that middle school students were "turned off" by textoriented computer-based instructional materials. They reported that students did not complete programs that used the computer as a page-turner with too much text and no capacity for creative interaction.

Page-turning does not involve the student in the learning and only makes the process of turning the page and reading the material more difficult. However, not all authors make this distinction. For example, Rosen (1995) says that "multimedia simply refers to the blending of two or more communication methods." This leads to a definition that includes simple presentation in the linear mode, just done in a "jazzier" way with more "bells and whistles" and which really does not take advantage of the potential of the computer. Lynch (1995a) calls ASTOUND a "media-oriented counterpart of the 'heavy-duty' presen-

Correspondence should be addressed to E. F. Rosen, Department of Psychology, College of William and Mary, P. O. Box 8795, Williamsburg, VA 23187-8795 (e-mail: efrose@facstaff.wm.edu). tation programs Persuasion and PowerPoint" (p. 11). Again, this is a further "muddying" of the water, since ASTOUND does not support "free" navigation. At best, these programs offer limited navigational controls, such as "forward" and "back." Authors need to be careful to make sure that the "power to the user" definition of multimedia (navigational control to the user) is the one being followed. Even in sales brochures, interactivity produces increased retention of the information presented (Davies, 1994).

By this definition, presentation software is not multimedia. Presentation software, such as ASTOUND, could be multimedia if the audience were allowed to control the path through the slides. However, "presentation" usually implies presenter control and passive audience. It is user or audience control that is the critical element of multimedia. It is learner as controller, learner as doer and explorer. Multimedia permits the user to become his/her own instructor. In multimedia programs, the user is the active agent in the learning process. Interaction is not just the ability to control navigation through the product but can also include control of choice and control of all media used in the program, whether slides, video clips, or animation. For example, with digital video, the user can be given controls that can halt the play, can rewind and start over, can step through the video frame by frame, and so forth (Stern, 1995).

Grunin, Smith, and Venditto (1995) argue that the distinction involves the logic of the program (presentation packages are mostly frame-based): the slide is designed first and then the slides are linked in some fashion. Multimedia programs, however, are logic-based: the program flow is defined first and the screens are second. Thus, they assert that the essential difference is between simple branching (for the presentation) and conditional branch- 
ing (for the multimedia training module). In conditional branching, the next screen depends upon the nature of the response to an object on the current screen.

\section{Some Characteristics of Authoring Languages}

Multimedia productions, like many other computer programs, depend upon the hardware and software available not only on the construction platform (the system on which the program will be developed) but also on the presentation platform (the system on which users gain access to the programs). These are not necessarily identical. Many of the "power builders" do their multimedia construction on the Macintosh platform, but the vast majority of users use the IBM-compatible PC platform. The decision as to which multimedia product is the appropriate one to use depends, therefore, on several factors that can be grouped loosely into three major considerations: (1) the goals of the project, (2) the hardware and software of the production machine, and (3) the hardware and software of the delivery system. Of these three, the most important consideration is the delivery system. Macintoshes account for only about a $10 \%-14 \%$ share of the personal computer market, although there is some dispute as to the percentage of the multimedia market being more like $40 \%$ for the Macintosh. Working in an academic environment, however, we know the machine for which we are designing.

Rosenthal (1995) claims that cross-platform multimedia tools are on their way. This authoring innovation will make choices and development of education programs less difficult because the same multimedia tools will be usable on both the PC and the Macintosh architecture types. Generally, the term cross-platform refers to use between Macs and PCs, but the time is coming when it will also include the use of game machines and the Internet. Rosenthal also points out that there are multiple metaphors for authoring. The oldest is the text instruction list, which is then compiled to run on either the Mac or the PC (e.g., SCRIPTX, C++). A second format is the use of the metaphor of a "score": events are used as "actors," which are then brought in and out of the frame and changed (e.g., AUTHORWARE, Director). The third general type is a two-layer model that combines menus, objects, and images at one level, with scripts at a second level (e.g., SUPERCARD). A fourth pattern is the flowchart metaphor (e.g., IconAuthor). Another metaphor is the object-oriented authoring program (e.g., MEDIAVERSE). They allow the user to reuse objects that are already developed and to add new objects.

Lynch (1994) points out, however, that even with the strong navigational control provided by these high-end authoring languages, the control opportunity offered the user of the multimedia package is quite limited relative to that offered the user of a package such as Microsoft Word, which includes about 150 menu choices. He points out that the screen interface apparently chosen by the multimedia package is more like the linear model of television than the multiple-pull-down-menu model of the Macintosh or of Windows. The screen metaphors of multi- media producers strive for the visually and aurally interesting in favor of a paucity of information. In fact, one adage of multimedia instructional authoring is not to clutter the screen with too much information. Typically, the navigational controls offered include "forward," "back," "go to the graphical menu page," and so forth. The heavy use of graphics serves to slow down the process, thereby rewarding the curious, nonlinear pursuit person, with long time lags needed to generate beautiful yet informationally impoverished screens. Lynch argues for the development of standard multimedia interfaces like the Windows menu system. As it stands now, there is no standard; each application has its own standard, which must be learned. This is like building automobiles, each with their own set of controls, so that the driver must learn how to drive each automobile in a different way. Lynch advocates the development of standard templates by the authoring languages' publishers so that the screen layouts will be standardized across applications. In fact, Multimedia Toolbook 3.0 does provide such a set of templates and also builds the basics of control and layout of the to-be-built application through a series of questions at the beginning of the development of a new book. The educational version of Authorware Professional also provides many templates for use by authors. Lynch asserts that SUPERCARD meets these criticisms as well.

Rosenthal (1995) discusses other issues in the delivery of the educational material to the learner. The playback capabilities and costs are tremendously variable. Most, however, aim to be small in size and fast for rapid playback. Some playback systems require payment for each copy used. Others include the right to reproduce the player with the purchase of the authoring language. Of course, other things to consider are the format of the multimedia materials supported (both input and output), the player mechanism provided, and the ability to link to databases.

A new exciting delivery possibility is the Internet. Many of the Web browsers promise multimedia capabilities. Currently, Web browsers, such as Netscape, use external programs (e.g., MediaPlayer) to playback the multimedia elements, but that support will soon become an integrated part of the browser (Rosenthal, 1995). Many commercial organizations see the Web as an exciting new source for advertising and, ultimately, sales (Stefanac, 1994). However, multimedia Web browsers are beyond the scope of this paper.

\section{Critical Issues in the Selection}

According to Locatis et al. (1992), the major considerations to take into account when deciding upon the appropriate authoring language to use should include the following: platform (operating system, RAM for authoring and for delivery, hard disk space); monitor and resolution required, video equipment and drivers supported and/or required (videodisc, videotape, cdrom, video camera); inputs supported (mouse, keyboard, touch screen, lightpen, voice-recognition, video overlay cards, digital video); audio supported; instructional capabilities (drill and practice, testing, tutorials, simulations, hypertext, hy- 
permedia, level of interactivity, kind of recordkeeping permitted, and hard drive requirements); network compatibility, utilities included with the package; linkages to other software packages; description of the user interface (pull-down menus, object-oriented programming possible, authoring metaphor); debugging tools; cost (list and educational discount, runtime costs, network licenses, site licenses); tutorial and/or on-line help; and vendor support. Wulfekuhle (1994) takes a different approach to selecting an authoring language. He suggests that there are three functions of a language that need to be considered: learner control, form of information presentation, and source data organization. He suggests that the best authoring language is the one that will produce a computerbased training module such that students can concentrate on the material rather than having to struggle to get through the program, with ease of operation, and availability of on-line help. Additionally, there needs to be some way to assess the effectiveness of the module, which means that the authoring language must provide some means for constructing such evaluation tools. It must have good audio and video capabilities. The language needs to be easy for the author to use: navigation controls should be simple to construct and to incorporate multimedia of various types. A helpful feature is that the authoring language has some means for incorporating "learning" fea- tures in the module. In this way, the module could grow with increasing numbers of diverse errors that students make. The authoring system needs to be able to link to other programs. It needs to have good text-handling abilities, since much of the information conveyed will be either in or accompanied by textual material.

Some of the critical issues or features of authoring languages that are important to the decision to be made are summarized in Table 1 for the two most commonly used authoring languages (ToolBook, Authorware/Director), for Supercard (which has been popular in the past and is now available in a new version), one that is very versatile relative to platform (IconAuthor), and one that is very basic and simple and readily available (Action!). We recommend that, in deciding on the authoring language for a particular situation, one should focus first on the user platform, then on the level of interactivity necessary (conditional vs. nonconditional branching), then on the need for database connectivity, and then on the support available and the appeal of the metaphor upon which the language is based. Purchase whatever you then need for the one authoring station you will use.

Our personal choice has been ToolBook Multimedia CBT. We chose this language because we are at schools that primarily use IBM-clone PCs. We were very concerned about user control of navigation. We did not need

Table 1

Summary of Features of Some Popular Authoring Languages

\begin{tabular}{|c|c|c|c|c|c|c|c|}
\hline \multirow[b]{2}{*}{ Feature } & \multicolumn{7}{|c|}{ Multimedia Authoring Language } \\
\hline & $\begin{array}{c}\text { Multimedia } \\
\text { ToolBook CBT }\end{array}$ & Director 4.0 & Authorware 3.0 & IconAuthor 6.0 & Action! & Supercard 2.5 & Quest 5.0 \\
\hline $\begin{array}{l}\text { Author } \\
\text { platform }\end{array}$ & Windows & $\begin{array}{l}\text { Mac, system } 7 \\
\text { Windows } \\
\text { (256 colors) }\end{array}$ & $\begin{array}{l}\text { Windows, } \\
\text { Mac, system } 7\end{array}$ & $\begin{array}{l}\text { OS } / 2, \text { UNIX, } \\
\text { Windows, } \\
\text { Windows NT }\end{array}$ & $\begin{array}{l}\text { Windows } \\
\text { Mac }\end{array}$ & $\mathrm{Mac}$ & Windows \\
\hline $\begin{array}{l}\text { Playback } \\
\text { platform }\end{array}$ & Windows & $\begin{array}{l}\text { Windows } \\
\text { ( } 256 \text { colors) } \\
\text { Mac, system } 6.07+\end{array}$ & $\begin{array}{l}\text { Windows } \\
\text { Mac, system 6+ }\end{array}$ & $\begin{array}{l}\text { Windows } \\
\text { Windows NT, } \\
\text { OS/2, Unix }\end{array}$ & Windows Mac & $\begin{array}{l}\text { Mac } \\
\text { Windows } \\
\text { (Runtime Player } \\
\text { available soon) }\end{array}$ & Windows \\
\hline $\begin{array}{l}\text { Minimum } \\
\text { RAM (MB) } \\
\text { (author) }\end{array}$ & 8 (12 better $)$ & $\begin{array}{l}\text { Mac: } 4+ \\
\text { Windows: } \\
8 \text { (16 better) }\end{array}$ & 4 ( 8 better $)$ & 8 & $\begin{array}{l}\text { Mac: } 4 \\
\text { Windows: } 4 \\
\text { ( } 8 \text { better) }\end{array}$ & $4+$ & 8 (16 better) \\
\hline $\begin{array}{l}\text { Hard disk } \\
\text { space (MB) } \\
\text { (author) }\end{array}$ & 20 minimum & $\begin{array}{l}\text { Mac: } 30 \\
\text { Windows: } 40\end{array}$ & 20 minimum & 20 & $3+$ & $4+$ & 10 minimum \\
\hline $\begin{array}{l}\text { Device } \\
\text { drivers used }\end{array}$ & MCI & $\begin{array}{l}\text { Proprietary } \\
\text { drivers }\end{array}$ & $\begin{array}{l}\text { Proprietary } \\
\text { drivers }\end{array}$ & MCI & Proprietary & Mac Drivers & $\mathrm{MCI}$ \\
\hline ODBC & yes(extra) & no & yes & no & no & $\mathbf{n} / \mathbf{a}$ & yes \\
\hline $\begin{array}{l}\text { Built-in } \\
\text { student } \\
\text { tracking }\end{array}$ & yes & no & yes & yes & no & no & yes \\
\hline $\begin{array}{l}\text { Network } \\
\text { compatibility }\end{array}$ & yes & yes & yes & yes & yes & yes & yes \\
\hline $\begin{array}{l}\text { Utilities } \\
\text { included }\end{array}$ & $\begin{array}{l}\text { digital video } \\
\text { producer, clipart, } \\
\text { media browser }\end{array}$ & none & $\begin{array}{l}\text { Director, } \\
\text { Clip Library, } \\
\text { Macromodel. } \\
\text { Soundforge, } \\
\text { Adobe Premier }\end{array}$ & none & none & $\begin{array}{l}\text { Videoshop, } \\
\text { Morph } 2.5 \text {. } \\
\text { Sound Mate }\end{array}$ & $\begin{array}{l}\text { FastTracks, } \\
\text { Quick Frames. } \\
\text { SmartSpots }\end{array}$ \\
\hline $\begin{array}{l}\text { Programming } \\
\text { language }\end{array}$ & Openscript & Lingo & Link & $\mathrm{C} / \mathrm{C}++$ & none & SuperTalk & $\begin{array}{l}\text { Quest C (ANSI } \\
\text { compatible) }\end{array}$ \\
\hline Metaphor & $\begin{array}{l}\text { books of pages } \\
\text { of scripted } \\
\text { objects }\end{array}$ & time-line & scripts & $\begin{array}{l}\text { flowchart of } \\
\text { icons of } \\
\text { events }\end{array}$ & time line & stacks of cards & flowline \\
\hline
\end{tabular}


Table 1 (Continued)

\begin{tabular}{|c|c|c|c|c|c|c|c|}
\hline \multirow[b]{2}{*}{ Feature } & \multirow[b]{2}{*}{$\begin{array}{c}\text { Multimedia } \\
\text { ToolBook CBT }\end{array}$} & \multirow[b]{2}{*}{ Director 4.0} & \multirow[b]{2}{*}{ Authorware 3.0} & \multirow[b]{2}{*}{ IconAuthor 6.0} & \multirow[b]{2}{*}{ Action! } & \multirow[b]{2}{*}{ Supercard 2.5} & \multirow[b]{2}{*}{ Quest 5.0} \\
\hline & & & & & & & \\
\hline $\begin{array}{l}\text { User } \\
\text { navigation }\end{array}$ & $\begin{array}{l}\text { conditional } \\
\text { available }\end{array}$ & $\begin{array}{l}\text { conditional } \\
\text { available }\end{array}$ & $\begin{array}{l}\text { conditional } \\
\text { available }\end{array}$ & $\begin{array}{l}\text { conditional } \\
\text { available }\end{array}$ & not conditional & $\begin{array}{l}\text { conditional } \\
\text { available }\end{array}$ & \\
\hline List price & $\$ 1,295$ & $\$ 1,195$ & $\$ 4,995$ & $\begin{array}{l}\$ 4,995 \\
\text { (OS/2, Windows); } \\
\$ 10,000 \text { (UNIX) }\end{array}$ & & $\$ 849$ & $\$ 3,995$ \\
\hline $\begin{array}{c}\text { Educational } \\
\text { discount }\end{array}$ & available & $\$ 590$ & $\begin{array}{l}\$ 965 \\
\text { (limited academic } \\
\text { version } \$ 150 \text { ) }\end{array}$ & & $\$ 99$ & $\begin{array}{l}\$ 249 \\
\text { (no utilities) }\end{array}$ & $\$ 995$ \\
\hline Runtime cost & free & free & free & $\begin{array}{l}\text { free for Windows } \\
\& \text { OS } / 2 ; \\
\$ 1,495 \text { for Mac; } \\
\$ 140 \text { UNIX } \\
\text { industrial }\end{array}$ & free & $\begin{array}{l}\text { Mac: no player } \\
\text { needed } \\
\text { Windows: free }\end{array}$ & free \\
\hline Tutorial & $\begin{array}{l}\text { yes; comes } \\
\text { with ToolBook } \\
\text { examples and } \\
\text { demonstrations } \\
\text { and on-line } \\
\text { tutorial and } \\
\text { help files }\end{array}$ & $\begin{array}{l}\text { two manuals; } \\
\text { tutorial files } \\
\text { with interactive } \\
\text { examples of } \\
\text { scripting }\end{array}$ & yes & yes & no & $\begin{array}{l}\text { four manuals; } \\
\text { paper-based } \\
\text { tutorial; no } \\
\text { SUPERCARD } \\
\text { examples; } \\
\text { some on-line } \\
\text { help }\end{array}$ & $\begin{array}{l}\text { six manuals; } \\
\text { tutorial }\end{array}$ \\
\hline Strength & hyperlinks & animation & $\begin{array}{l}\text { imports } \\
\text { Director files } \\
\text { directly }\end{array}$ & $\begin{array}{l}\text { content stored } \\
\text { in native format } \\
\text { separate from } \\
\text { structure }\end{array}$ & simple & $\begin{array}{l}\text { HyperCard } \\
\text { compatible }\end{array}$ & text-analysis \\
\hline $\begin{array}{l}\text { Vendor } \\
\text { support }\end{array}$ & $\begin{array}{l}\text { bulletin board } \\
\text { AOL, } \\
\text { discussion list, } \\
60 \text { days free } \\
\text { phone support } \\
\text { then } \$ 295 / \text { year, } \\
\$ 795 / \text { year for } \\
\text { developer } \\
\text { services; } \\
\text { courses (fee) }\end{array}$ & $\begin{array}{l}\text { free phone } \\
\text { support (toll) } \\
\text { calls; America } \\
\text { Online }\end{array}$ & $\begin{array}{l}\text { unlimited toll } \\
\text { calls; America } \\
\text { Online; e-mail } \\
\text { discussion list; } \\
\text { courses (fee) }\end{array}$ & 90-days toll-free & & $\begin{array}{l}\text { America Online } \\
\text { (users group); } \\
\text { technical } \\
\text { support phone }\end{array}$ & $\begin{array}{l}90 \text { days free } \\
\text { (toll call); } \\
\text { bulletin board } \\
\text { users group } \\
\text { starting }\end{array}$ \\
\hline Company & $\begin{array}{l}\text { Asymetrix } \\
\text { Bellevue, } \\
\text { WA } 98004\end{array}$ & $\begin{array}{l}\text { Macromedia } \\
\text { San Francisco, } \\
\text { CA } 94103\end{array}$ & $\begin{array}{l}\text { Macromedia } \\
\text { San Francisco, } \\
\text { CA } 94103\end{array}$ & $\begin{array}{l}\text { AimTech } \\
\text { Corporation }\end{array}$ & $\begin{array}{l}\text { Macromedia } \\
\text { San Francisco, } \\
\text { CA } 94103\end{array}$ & $\begin{array}{l}\text { Allegiant Tech. } \\
\text { San Diego, } \\
\text { CA } 92121\end{array}$ & $\begin{array}{l}\text { Allen Comm. } \\
\text { Salt Lake City, } \\
\text { UT } 84116\end{array}$ \\
\hline Phone & (206) 462-0501 & (800) 288-4797 & (415) 252-2000 & (800) 289-2884 & (415) $252-2000$ & (619) 587-0500 & (801) 537-7800 \\
\hline $\begin{array}{l}\text { World-Wide } \\
\text { Web address }\end{array}$ & $\begin{array}{l}\text { http: / www.asy } \\
\text { metrix.com }\end{array}$ & $\begin{array}{l}\text { http://www.mac } \\
\text { romedia.com }\end{array}$ & $\begin{array}{l}\text { http://www.mac } \\
\text { romedia.com }\end{array}$ & $\begin{array}{l}\text { http://www.aimt } \\
\text { ech.com }\end{array}$ & $\begin{array}{l}\text { http://www.mac } \\
\text { romedia.com }\end{array}$ & $\begin{array}{l}\text { http://www.alleg } \\
\text { iant.com }\end{array}$ & $\begin{array}{l}\text { http://www.allen } \\
\text { comm.com }\end{array}$ \\
\hline Reviews & Watterson (1994) & Lynch (1995b) & Raskin (1994) & Rosenthal (1995) & Lynch (1995a) & Rosenthal (1994) & \\
\hline
\end{tabular}

database connectivity beyond that provided by DDE links. The book metaphor and object-oriented programming has particular logical appeal to us. As academics, we are used to thinking about textbooks. Additionally, training courses were readily available to us (the Institute for Academic Technology). There is a strong discussion list on the Internet for ToolBook so that help is readily available. Another colleague at William and Mary was already using ToolBook, and we were already familiar with HyperCard programming, which is very similar to OpenScript (the ToolBook programming language). We purchased the hardware necessary for the authoring system. Finally, the price of ToolBook was within the range of our budget with the academic discount. We have been very satisfied with our choice. The Toolbook discussion list is very active and extremely helpful. The upgrades in the program since we first started using it (Toolbook 1.0) have been very good. The current version offers an introductory interview format when first starting a project, with template pages and preprogrammed utilities for tracking student progress and for navigation. Starting to use Toolbook was easy, but, like all packages, the learning curve for anything requiring any programming was steep unless automatic script recording could be used. However, support from outside sources was available, and we have successfully produced and used some programs for our classes (Petty, Lynch, \& Rosen, 1993; Rosen \& Petty, 1992). We continue to do so. Toolbook is also effective for presentations, and we use it for that purpose in classes. We have also used it to administer a laboratory examination in a graduate course in physiological psychology and for presenting stimulus pictures for a research project.

\section{Conclusions}

Multimedia authoring languages are continually being improved and upgraded (e.g., Multimedia Toolbook 4.0 was just released this winter). As new and faster equipment is released, multimedia capabilities grow rapidly. 
In a constantly evolving medium such as this, the authoring language choice will probably be made many times. Also, as needs change, the appropriate language may change. Do not believe that a language choice is for a lifetime. To further complicate choices, new languages are constantly being developed. As a consequence, the data table provided here is already out of date. Fortunately, NewMedia magazine has replaced its annual buyer's guide with a Web site (http://www.hyperstand.com), replete with tables such as that presented here.

At the same time, do not wait for the development of the "perfect" system. A new and better "widget" is always just on the horizon: waiting can be for a long, long time. Remember that learning is a life-long affair and multimedia authoring is a life-long learning process.

\section{REFERENCES}

DAviES, J. (1994). Stop the presses! Creating an electronic brochure. In J. Keyes (Ed.), The McGraw Hill multimedia handbook (pp. 21.121.19). New York: McGraw Hill.

Grunin, L., Smith, G., \& Venditto, G. (1995). Multimedia authoring. Windows Sources, 3(6), 64-110.

Locatis, C., Ullmer, E., Carr, V., Banvard, R., Lo, R., Le, Q., \& WiLliaMSON, M. (1992). Authoring systems. Lister Hill Monograph, LHNCBC 92(1)

LYNCH, P. J. (1994). The evolving face of multimedia. Syllabus, 8(3), 48-50.
LYNCH, P. J. (1995a). Entry-level multimedia authoring tools for education. Syllabus, 8(8), 10-18.

LYNCH, P. J. (1995b). Macromedia director 4.0 for Windows. Syllabus, 8(6), 35-37.

Peterson, N. K., \& ORDE, B. J. (1995). Implementing multimedia in the middle school curriculum: Pros, cons and lessons learned. T.HE. Journal, 22(7), 70-75.

PeTty, L. C., LynCh, E. A., \& Rosen, E. F. (1993). A computer program to develop course objectıves and assessment measures. Behavior Research Methods, Instruments, \& Computers, 25, 281-286.

RASKIN, R. (1994). Creating multimedia to die for. PC Magazine, 13(4), 209-251.

Rosen, D. (1995). Multimedia building blocks. Multimedia Online, 1, 8-22.

Rosen, E. F., \& PetTy, L. C. (1992). Computer-aided instruction in a physiological psychology course. Behavior Research Methods, Instruments, \& Computers, 24, 169-171.

Rosenthal, S. (1994). SuperCard 1.7. NewMedia, 4(11), 96-98.

Rosenthal, S. (1995). Multimedia authoring isn't just a two-way street. NewMedia, 5(5), 39-42.

STEFANAC, S. (1994). Multimedia meets the Internet. NewMedia, 4(11), 56-63.

STERN, J. (1995). Digital video for educators. Syllabus, 8(4), 10-13.

WATTERSON, K. (1994). An update that's worth the wait. Windows Sources, 2(8), 80-82.

WULFEKUHLE, N. (1994). Selecting a hypermedia authoring program for CBT. T.H.E. Journal, 21(7), 77-80.

(Manuscript received November 13, 1995; revision accepted for publication January 30, 1996.) 